\title{
Right heart failure caused by metastatic renal cell carcinoma masquerading as an obstructive cardiac tumour
}

\author{
Abhishek Chandrakant Sawant, ${ }^{1}$ Pradeep R Atla, ${ }^{1}$ Sanjay S Srivatsa, ${ }^{2}$ Pervaiz Chaudhry ${ }^{3}$ \\ ${ }^{1}$ Department of Internal Medicine, Community Regional Medical Center, Fresno, California, USA \\ ${ }^{2}$ Division of Cardiology, Community Regional Medical Center, Fresno, California, USA \\ ${ }^{3}$ Department of Cardiothoracic Surgery, Community Regional Medical Center, Fresno, California, USA \\ Correspondence to Dr Abhishek Chandrakant Sawant, acsawant@buffalo.edu
}

\section{DESCRIPTION}

We present a rare case of renal cell carcinoma (RCC) in a 58-year-old Hispanic woman presenting with progressive shortness of breath of 2 months duration. Physical examination was remarkable for jugular venous distension, pedal oedema and left flank fullness. An initial transthoracic echocardiogram revealed a large, greater than $4 \times 3 \mathrm{~cm}$ solid mass extending from the inferior vena cava (IVC) into the right atrium (figure 1). Subsequently, a 64-slice contrast-enhanced axial helical CT scan of the chest, abdomen and pelvis revealed a very large lobulated heterogeneously enhancing mass $12.4 \times 9.5 \mathrm{~cm}$ occupying most of the left kidney. There was evidence of contiguous tumour extension into the left renal vein and IVC. Tumour invasion into the posterior wall of the IVC, extending into the right atrium was demonstrated (figure 2). $M R$ angiogram showed three left renal arteries supplying the tumour mass, which were treated with embolisation before surgery (figure 3).

On the basis of multimodality imaging, the tumour was staged at T3c. The cardiac tumour extension was initially resected with reconstruction of the posterior wall of the right atrium and IVC under cardiopulmonary bypass. Subsequently, left radical nephrectomy was performed. Pathology from both specimens confirmed clear-type RCC (figure 4).
Previous case reports have demonstrated metastatic RCC extending into the right atrium presenting as syncope. ${ }^{1}$ Our patient's heart failure symptoms were likely secondary to physical obstruction in the right atrium from the tumour extension. This rare presentation ( $1 \%$ cases) of RCC extending to the right atrium highlights the silent nature of RCC before being diagnosed. Although, the RCC along with its tumour extensions was successfully resected, the high risk of recurrence mandates lifelong surveillance. ${ }^{2}$

\section{Learning points}

Direct cardiac metastasis is an uncommon (1\% cases) presentation of primary renal cell cancer.

- Multimodality imaging is required for accurate diagnosis, staging and treatment of intracardiac metastasis of renal cell cancer.

- Owing to high risk of recurrence, lifelong surveillance is mandatory.

Competing interests None.

Patient consent Obtained.

Figure 1 Transthoracic echocardiogram apical four-chamber view showing a $4 \times 3 \mathrm{~cm}$ mass in the right atrium extending from the inferior vena cava (white arrow). 


\section{BMJ Case Reports}

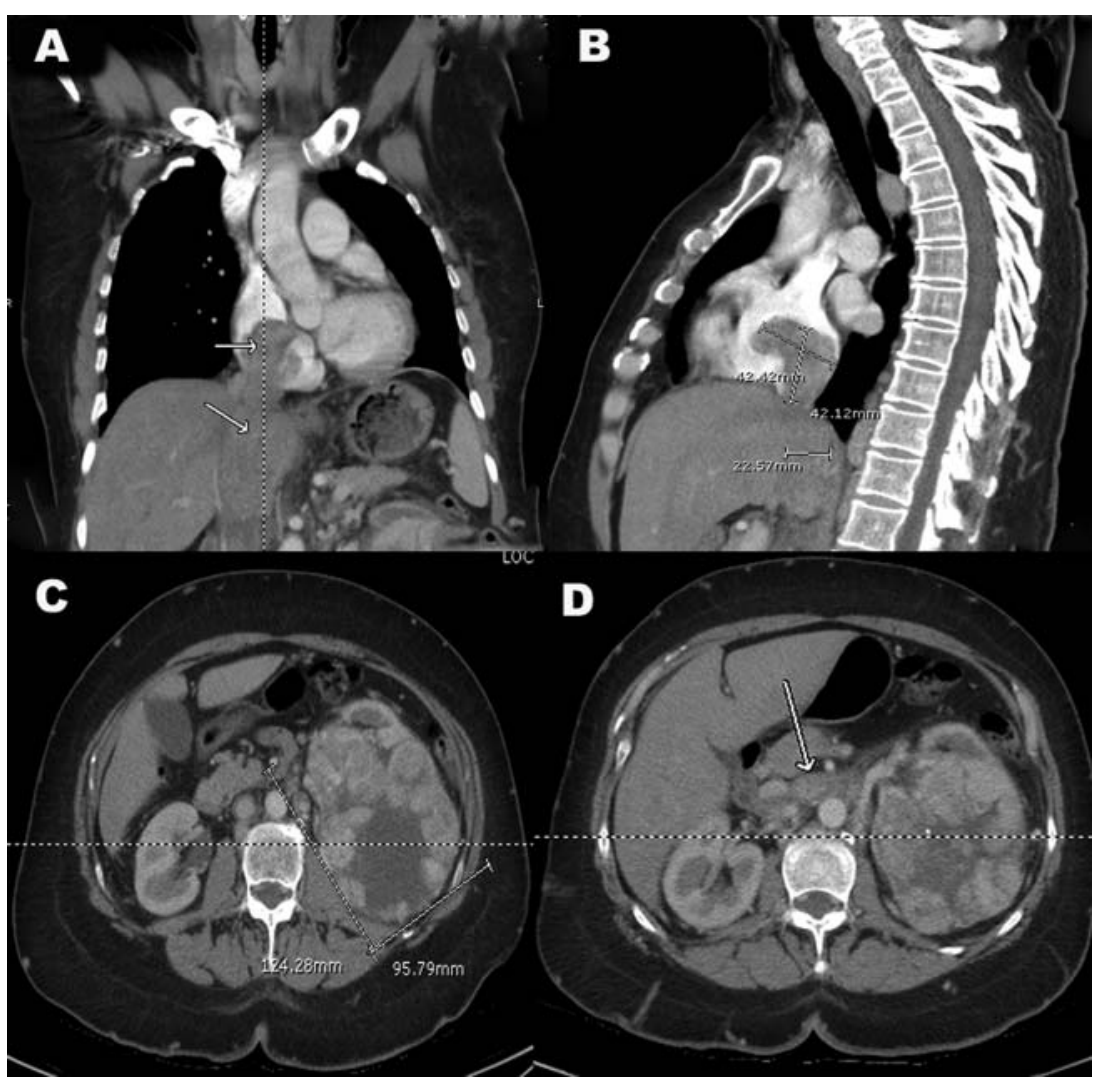

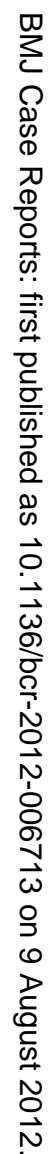

Figure 2 Contrast-enhanced CT (A) coronal and (B) sagittal sections of the chest showing an intra-atrial mass adherent to the posterior wall of right atrium, (C) axial sections of the abdomen and pelvis showing $12.4 \times 9.5 \mathrm{~cm}$ renal cell carcinoma and (D) invasion into the inferior vena cava (white arrow).

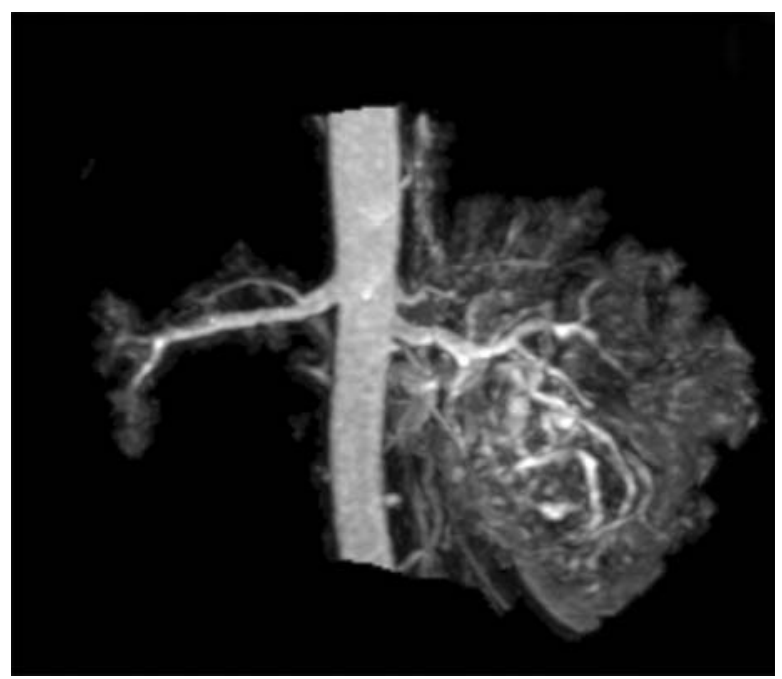

Figure 3 MR angiogram showing three left renal arteries supplying the large tumour. 


\section{BMJ Case Reports}

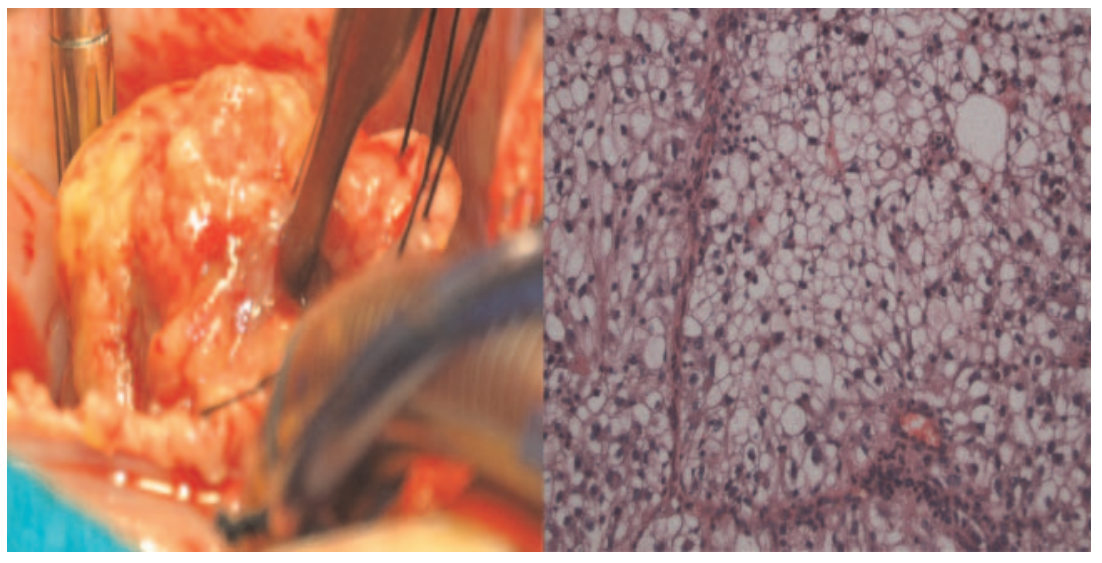

Figure 4 (A) Intraoperative image of the right atrial tumour and (B) microscopy showing a nest of tumour cells with clear cytoplasm, low nuclear grade and delicate capillary network.

\section{REFERENCES}

1. Alghamdi A, Tam J. Cardiac metastasis from a renal cell carcinoma. Can J Cardiol 2006;22:1231-2.
2. Chae EJ, Kim JK, Kim SH, et al. Renal cell carcinoma: analysis of postoperative recurrence patterns. Radiology 2005;234: $189-96$

This pdf has been created automatically from the final edited text and images.

Copyright 2012 BMJ Publishing Group. All rights reserved. For permission to reuse any of this content visit http://group.bmj.com/group/rights-licensing/permissions.

BMJ Case Report Fellows may re-use this article for personal use and teaching without any further permission.

Please cite this article as follows (you will need to access the article online to obtain the date of publication).

Sawant AC, Atla PR, Srivatsa SS, Chaudhry P. Right heart failure caused by metastatic renal cell carcinoma masquerading as an obstructive cardiac tumour. BMJ Case Reports 2012;10.1136/bcr-2012-006713, Published XXX

Become a Fellow of BMJ Case Reports today and you can:

- Submit as many cases as you like

- Enjoy fast sympathetic peer review and rapid publication of accepted articles

- Access all the published articles

Re-use any of the published material for personal use and teaching without further permission

For information on Institutional Fellowships contact consortiasales@bmjgroup.com

Visit casereports.bmj.com for more articles like this and to become a Fellow 